\title{
PENGARUH MANAJEMEN LIKUIDITAS, MANAJEMEN ASET DAN MANAJEMEN UTANG TERHADAP LABA
}

\author{
Indra Satria \\ Universitas Pancasila, Indonesia \\ Email: indra_satria_feup@yahoo.co.id
}

\begin{abstract}
Abstrak: Pengaruh Manajemen Likuiditas, Manajemen Aset dan Manajemen Utang Terhadap Laba. Penelitian ini bertujuan untuk mengemukakan model regresi linier berganda yang dapat digunakan sebagai model penaksir terhadap laba. Penelitian dilakukan terhadap perusahaan porselin, keramik dan gelas yang listing di BEI pada periode 2009-2015, memunyai laporan keuangan auditan dan memeroleh laba selama periode tersebut. Variabel independen dalam penelitian ini adalah Current Ratio (CR), Total Assets Turnover Ratio (TATO), dan Debt Ratio (DR). Ketiga variabel ini masing-masing digunakan sebagai proksi manajemen likuiditas, manajemen aset, dan manajemen utang. Sementara, Return on Assets Ratio (ROA) adalah variabel dependen yang digunakan sebagai proksi laba. Hasil penelitian menunjukkan bahwa manajemen likuiditas, manajemen aset dan manajemen utang berpengaruh signifikan terhadap laba.
\end{abstract}

Kata kunci: Current Ratio, Debt Ratio, Return on Asset, Total Asset Turnover

\begin{abstract}
Effect of Liquidity Management, Asset Management and Liability Management on Profit. The purpose of this research is to propose a multiple linear regression model that can be used as a profit prediction model. The research was conducted to the porcelain, ceramic and glass companies listed in Indonesian Stock Exchange for the period of 2009-2015. They had to have audited financial reports and make a profit over that period. In this research, the independent variables were Current Ratio (CR), Total Assets Turnover Ratio (TATO), and Debt Ratio (DR). These variables were used as proxy for liquidity management, asset management, and liability management. Meanwhile, Return on Assets ratio (ROA) was dependent variable used as a proxy for profit. The result showed that liquidity management, asset management and debt management have significant effect on profit.
\end{abstract}

Keyword: Current Ratio, Debt Ratio, Return on Asset, Total Asset Turnover

\section{PENDAHULUAN}

Membahas mengenai laba, sepertinya tidak akan pernah ada masa kadaluarsanya. Karena, sebagian besar perusahaan pada dasarnya didirikan untuk mampu menghasilkan laba. Semakin tinggi tingkat laba, semakin tinggi tingkat efisiensi dan efektivitas operasional perusahaan. Dengan demikian, semakin tinggi pula tingkat kemampuan perusahaan untuk menjaga kelangsungan usahanya dalam jangka panjang.

Beberapa ahli ekonomi telah mengemukakan pendapatnya mengenai tiga faktor utama yang memengaruhi laba yaitu manajemen likuiditas, manajemen aset dan manajemen. Mengutip pernyataan yang disampaikan oleh Ehrhardt \& Brigham (2011:98), laba mencerminkan dampak dari kombinasi manajemen likuiditas, 
manajemen aset dan manajemen utang. Manajemen likuiditas tercermin melalui kebijakan terhadap tingkat Current Ratio dan Quick Ratio. Sementara, kebijakan manajemen aset dapat terlihat melalui tingkat Inventory Turnover Ratio, Days Sales Outstanding Ratio, Fixed Assets Turnover Ratio, dan Total Assets Turnover Ratio. Selanjutnya, kebijakan manajemen utang dapat diamati melalui tingkat Debt Ratio, Debt to Equity Ratio, Times Interest Earned Ratio, dan Earnings Before Interest, Tax, Depreciation and Amortization (EBITDA) Coverage Ratio. Berkenaan dengan hal itu, ukuran laba dapat dinyatakan melalui rasio Net Profit Margin, Basic Earning Power, Return on Equity, dan Return on Assets (atau Return on Investment).

Pendapat tersebut didukung oleh Fraser \& Ormiston (2010:213), yang menyatakan bahwa likuiditas berpengaruh terhadap laba; laba diawali dengan penjualan yang berkaitan dengan persediaan. Semakin tinggi tingkat perputaran persediaan, semakin tinggi kemampuan perusahaan memeroleh laba. Tingkat perputaran persediaan yang tinggi, harus diiringi dengan tingkat perputaran piutang usaha. Semakin tinggi tingkat perputaran piutang usaha, semakin tinggi tingkat penerimaan kas. Dengan demikian, perusahaan mampu membayar utang yang digunakan dalam mendanai aset. Bila suatu perusahaan yang bergerak dalam bidang properti dan pabrikasi, perusahaan memerlukan investasi yang ekstensif dalam aset tetap. Untuk itu, Fixed Asset Turnover dan Total Asset Turnover merupakan dua pendekatan yang dapat digunakan untuk menilai efektivitas penggunaan aset dalam menghasilkan penjualan.
Pendapat serupa dinyatakan oleh Keown, et.al (2014:112), yang berpendapat bahwa laba diperoleh melalui aset yang diinvestasikan oleh pemegang saham. Perusahaan juga mungkin memeroleh utang dari pihak eksternal bagi kepentingan investasi perusahaan, dengan maksud menghasilkan laba. Keown (2014:408) juga mengemukakan hal yang lebih spesifik mengenai pengaruh utang terhadap laba. Pada saat kondisi ekonomi menurun, memiliki jumlah utang dalam jumlah besar akan menimbulkan kegagalan bagi perusahaan dalam membayar pokok dan bunga pinjaman. Sebaliknya, pada saat kondisi ekonomi meningkat, memiliki jumlah utang dalam jumlah yang besar akan menguntungkan bagi perusahaan. Dengan demikian, perusahaan harus mampu mengelola tingkat utang pada tingkat biaya dan manfaat yang seimbang.

Pendapat lainnya juga menyatakan bahwa laba merupakan pengaruh dari keputusan masa lalu dalam bentuk investasi, operasi dan pendanaan perusahaan selama suatu periode (Helfert, 2001:95). Beberapa keputusan utama, seperti investasi dalam peralatan pabrik baru atau penambahan lini produk, menimbulkan utang dalam jumlah besar. Banyak dari keputusan lainnya, menyangkut kebijakan operasional dalam mengelola sumber daya perusahaan. Kombinasi dari berbagai keputusan tersebut pada dasarnya menyangkut pertimbangan ekonomis antara penerimaan kas yang diharapkan dengan kas yang dikeluarkan.

Beberapa penelitian yang berkenaan dengan faktor yang memengaruhi laba banyak telah dilakukan. Berbagai model regresi pun dikemukakan untuk dapat 
digunakan sebagai model penaksir laba. Umumnya, rasio keuangan digunakan sebagai proksi laba maupun faktor-faktor yang memengaruhi laba tersebut. Laba diproksikan dengan rasio, seperti: Return on Asset (ROA), Return on Investment (ROI), dan Return on Equity (ROE). Sementara, faktorfaktor penentu laba diproksikan dengan rasio, seperti; Current Ratio (CR), Quick Ratio (QR), Total Assets Turnover (TATO), Inventory Turnover (ITO), Debt Ratio (DR), Working Capital Turnover (WCT), Time Interest Earned Ratio (TIER), Degree of Financial Leverage (DFL), Cash Ratio, Cash Conversion Cycle (CCC), dan Debt to Equity Ratio (DER). Beberapa penelitian yang berhasil diperoleh sebagai rujukan dalam penelitian ini dinyatakan seperti berikut ini.

Sanjaya, dkk (2015) menyatakan bahwa secara parsial maupun simultan, CR, TATO dan WCT tidak berpengaruh signifikan terhadap ROA. Hasil pengujian menunjukkan bahwa pengaruh CR, TATO dan WCT terhadap ROA (terlihat dari nilai adjusted $\mathrm{R}$ square) adalah sebesar $-95,1 \%$. Karena pengaruhnya bernilai negatif, hasil penelitian ini memberikan kesimpulan yang sangat tidak diharapkan.

Ristanti, dkk (2015) menyatakan bahwa CR dan WCT secara parsial tidak berpengaruh signifikan terhadap ROI. Namun, secara simultan CR dan WCT berpengaruh signifikan terhadap ROI. Hasil pengujian menunjukkan bahwa pengaruh CR dan WCT terhadap ROI adalah sebesar $56,3 \%$. Penelitian ini memuat kesimpulan tentang pengaruh manajemen likuiditas dan manajemen utang terhadap laba.

Noor \& Lestari (2012) menyatakan bahwa hanya WCT yang berpengaruh signifikan terhadap ROI. Secara simultan, CR, WCT dan DR tidak berpengaruh signifikan terhadap ROI. Hasil pengujian menunjukkan bahwa pengaruh CR, WCT dan DR terhadap ROI hanyalah sebesar $3,2 \%$. Penelitian ini memuat kesimpulan tentang pengaruh manajemen likuiditas dan manajemen utang terhadap laba.

Wibowo \& Wartini (2012) menguji pengaruh WCT, CR, dan DR terhadap ROI. Secara parsial, hanya variabel WCT yang berpengaruh signifikan terhadap ROI. Secara simultan, WCT, CR, DR berpengaruh signifikan terhadap ROI. Hasil analisis regresi menunjukkan bahwa pengaruh WCT, CR, dan DR terhadap ROI hanyalah sebesar 21,9\%. Komponen variabel independen yang digunakan dalam penelitian ini seiring dengan penelitian Noor \& Lestari (2012).

Barus \& Leliani (2013) menguji pengaruh TATO, DR, ukuran perusahaan, CR, DER dan pertumbuhan penjualan terhadap ROA. Ia berpendapat bahwa secara parsial hanya TATO, DR dan ukuran perusahaan yang berpengaruh signifikan terhadap ROA. Secara simultan, TATO, CR, DR, ukuran perusahaan, DER dan pertumbuhan penjualan berpengaruh signifikan terhadap ROA. Hasil pengujian menunjukkan bahwa pengaruh TATO, DR, ukuran perusahaan, CR, DER dan pertumbuhan penjualan terhadap ROA sebesar $30,1 \%$. Penelitian ini memuat kesimpulan tentang pengaruh manajemen likuiditas, manajemen aset dan manajemen utang terhadap laba.

Sari \& Chabachib (2013) menguji pengaruh DER, TATO, dan Sales terhadap ROA. la berpendapat bahwa secara parsial DER, TATO, dan Sales berpengaruh signifikan terhadap ROA. Hasil penelitian menunjukkan 
kecilnya pengaruh variabel DER, TATO, dan sales terhadap ROA yaitu sebesar $29,7 \%$. Penelitian ini memuat kesimpulan tentang pengaruh manajemen utang dan manajemen aset terhadap laba.

Ismail (2016) menguji pengaruh CR, QR, CCC, dan Cash Ratio terhadap ROA. Ia menemukan bahwa hanya CR dan CCC yang berpengaruh signifikan terhadap ROA. Hasil pengujian menunjukkan bahwa pengaruh CR, QR, CCC, dan Cash Ratio terhadap ROA hanyalah sebesar $24,7 \%$. Penelitian ini memuat kesimpulan tentang pengaruh manajemen likuiditas terhadap laba.

Rosyadah, dkk (2013) mengemukakan bahwa secara parsial dan simultan, DR dan DER berpengaruh signifikan terhadap ROA maupun ROE. DER dan DR memberikan pengaruh terhadap ROA hanya sebesar $11,9 \%$ dan hanya berpengaruh 27,1\% terhadap ROE. Penelitian ini memuat kesimpulan tentang pengaruh manajemen utang terhadap laba.

Novita \& Sofie (2015) menguji pengaruh DER dan CR terhadap ROA maupun ROE. Secara parsial maupun simultan, DER dan CR berpengaruh signifikan terhadap ROA ataupun ROE. DER dan CR memberikan pengaruh terhadap ROA sebesar $41,4 \%$ dan hanya berpengaruh $19,7 \%$ terhadap ROE. Penelitian ini memuat kesimpulan tentang pengaruh manajemen likuiditas dan manajemen utang terhadap laba.

Dwiarti (2014) menguji pengaruh TATO, CR, DER, PER, dan ITO terhadap ROE pada tahun 2010 dan 2011. Hasil pengujian data tahun 2010 dan 2011 menunjukkan bahwa hanya TATO yang berpengaruh signifikan terhadap ROE. Secara simultan, TATO, CR, DER, PER, dan ITO tidak berpengaruh signifikan terhadap ROE pada tahun 2010. Namun, kelima variabel ini berpengaruh secara simultan pada tahun 2011. Pengaruh TATO, CR, DER, PER, dan ITO terhadap ROE pada tahun 2010 hanyalah sebesar 6,5\%. Sementara, pengaruh TATO, CR, DER, PER, dan ITO terhadap ROE pada tahun 2011 sebesar 30,9\%.

Ritonga, dkk (2014) menguji pengaruh DR, DER, TIER dan DFL terhadap ROE. Ia berpendapat bahwa secara parsial hanya DR yang berpengaruh signifikan terhadap ROE. Hasil pengujian ini mampu menunjukkan bahwa DR, DER, TIER dan DFL berpengaruh signfikan terhadap ROE dengan nilai sebesar $90,8 \%$. Penelitian ini memuat kesimpulan tentang pengaruh manajemen utang terhadap laba. Pengaruh manajemen utang terhadap laba bernilai sangat tinggi. Namun, model regresi ini belum dapat digunakan sebagai penaksir laba karena hanya memuat pengaruh manajemen utang terhadap laba.

Kurniawati, dkk (2015) menguji pengaruh DFL, DR, DER and TIER terhadap ROE. Secara simultan, DFL, DR, DER and TIER berpengaruh signifikan hanya sebesar $22,6 \%$ terhadap ROE. Secara parsial, hanya DFL yang tidak berpengaruh signifikan terhadap ROE. Penelitian ini menggunakan variabel yang sama dengan penelitian Ritongga, dkk (2014).

Mengutip pendapat Ghozali (2006:83), model regresi yang baik dapat diukur dari nilai koefisien determinasi, nilai statistik $F$ dan nilai statistik $t$. Suatu model regresi yang baik menunjukkan nilai koefisien determinasi yang mendekati 100\%. Dengan demikian, variabel-variabel independen tersebut memberikan hampir semua informasi yang dibutuhkan untuk memprediksi variasi 
variabel dependen. Pengaruh variabelvariabel independen (terlihat dari uji nilai statistik $t$ dan uji nilai statistik F), selayaknya juga menunjukkan pengaruh signifikan terhadap variabel dependen.

Melengkapi pernyataan tersebut, pendapat yang disampaikan oleh Insukindro sebagaimana dikutip oleh Ghozali (2006:83), menyatakan bahwa koefisien determinasi hanyalah salah satu dan bukan satu-satunya kriteria memilih model yang baik. Alasannya, bila suatu estimasi regresi linier menghasilkan koefisien determinasi yang tinggi, tetapi tidak konsisten dengan teori ekonomi yang dipilih oleh peneliti, atau tidak lolos dari uji asumsi klasik, maka model tersebut bukanlah model penaksir yang baik dan seharusnya tidak dipilih menjadi model empirik.

Mengacu kepada pendapat Ghozali dan Insukindro tersebut, dapat dikatakan bahwa umumnya hasil-hasil penelitian diatas belum menghasilkan model regresi yang dapat dijadikan model penaksir yang baik terhadap laba. Umumnya koefisien determinasi bernilai rendah atau hanya sebagian kecil variabel independen yang berpengaruh signifikan terhadap laba. Hal tersebut mungkin disebabkan oleh ketersediaan data penelitian sehingga menunjukkan fakta demikian, ataupun akibat pemilihan variabel independen yang kurang tepat.

Berdasarkan kenyataan tersebut, penulis tertarik pula untuk melakukan penelitian yang serupa. Selain untuk melengkapi penelitian yang telah ada, tujuan utamanya adalah agar dapat menemukan model penaksir yang baik terhadap laba. Karena itu, topik yang dipilih adalah pengaruh manajemen likuiditas, manajemen aset dan manajemen utang terhadap laba.

\section{METODE}

Penelitian ini termasuk sebagai penelitian kausalitas, karena bertujuan untuk menentukan pengaruh manajemen likuiditas, manajemen aset dan manajemen utang terhadap laba. Untuk menentukan pengaruh tersebut, data penelitian dianalisis secara statistik menggunakan metode regresi linier berganda.

Populasi dalam penelitian adalah perusahaan sektor porselin, keramik, dan gelas yang listing di Bursa Efek Indonesia (BEI) periode 2009-2015, memunyai laporan keuangan auditan dan memeroleh laba selama periode tersebut. Berdasarkan pengamatan terhadap enam perusahaan yang listing di BEI pada periode tersebut, hanya tiga perusahaan yang memenuhi kriteria diatas. Perusahaan yang memenuhi kriteria adalah PT Surya Toto Indonesia Tbk, PT Asahimas Flat Glass Tbk, dan PT Arwana Citramulia Tbk. Tiga perusahaan lainnya yang terdaftar di sektor ini tidak memenuhi syarat karena pernah mengalami kerugian pada periode tersebut. Dengan demikian, populasi dalam sektor ini hanya tiga perusahaan. Karena jumlah populasi sangat kecil, tidak perlu dilakukan sampling melainkan sensus.

Pemilihan terhadap perusahaan di sektor porselin, keramik dan gelas dipertimbangkan karena masih sangat terbatasnya penelitian terhadap sektor ini. Selain itu, masingmasing sektor usaha terkadang menunjukkan kebijakan manajemen likuiditas, manajemen aset, dan manajemen utang yang berbeda pengaruhnya terhadap laba. 
Tabel 1. Definisi Operasional Variabel

\begin{tabular}{|c|c|c|c|}
\hline Variabel & Definisi variabel & Pengukuran & Skala \\
\hline \multicolumn{4}{|l|}{ Variabel dependen } \\
\hline Return on Asset (ROA) & $\begin{array}{l}\text { Ukuran kemampuan perusahaan } \\
\text { dalam menghasilkan laba }\end{array}$ & $\frac{\text { Laba komprehensif }}{\text { Total aset }}$ & Rasio \\
\hline \multicolumn{4}{|l|}{ Variabel independen } \\
\hline Current Ratio (CR) & $\begin{array}{l}\text { Ukuran kemampuan perusahaan } \\
\text { dalam memenuhi kewajiban lancar }\end{array}$ & $\frac{\text { Total aset lancar }}{\text { Total aset }}$ & Rasio \\
\hline Total Asset Turnover (TATO) & $\begin{array}{l}\text { Ukuran kemampuan perusahaan } \\
\text { dalam menghasilkan pendapatan } \\
\text { melalui aset yang dimilikinya. }\end{array}$ & $\frac{\text { Total penjualan }}{\text { Total aset }}$ & Rasio \\
\hline Debt Ratio (DR) & $\begin{array}{l}\text { Ukuran besarnya jumlah aset } \\
\text { perusahaan yang didanai dengan } \\
\text { utang }\end{array}$ & $\frac{\text { Total liabilitas }}{\text { Total aset }}$ & Rasio \\
\hline
\end{tabular}

Data penelitian berupa laporan keuangan auditan diperoleh dari Bursa Efek Indonesia dan diakses melalui situs www.idx.co.id. Komponen laporan yang diperlukan meliputi: laba komprehensif, total penjualan, total aset, total aset lancar, dan total liabilitas.

Variabel-variabel operasional yang diteliti adalah manajemen likuiditas, manajemen aset, manajemen utang, dan laba. Komponen variabel tersebut disajikan pada tabel 1. Laba diproksikan sebagai Return on Asset (ROA). Menurut Kasmir (2012:201), ROA memberikan ukuran yang lebih baik atas laba perusahaan. ROA diperhitungkan dengan cara membagi laba bersih dengan total aset (Helfert, 2001:112; Fraser \& Ormiston, 2010:198; Ehrhardt \& Brigham, 2011:100). Dalam penelitian ini, ROA diperhitungkan dengan cara membagi total laba komprehensif terhadap total aset. Laba komprehensif digunakan sebagai pengganti laba bersih, seiring dengan telah berubahnya pelaporan laba berdasarkan Standar Akuntansi Keuangan.
Manajemen likuiditas diproksikan sebagai Current Ratio (CR), yang ditentukan dengan membandingkan antara total aset lancar terhadap total aset (Platt dan Platt 2008). Pada umumnya, Current Ratio digunakan untuk mengukur tingkat likuiditas perusahaan (Fraser \& Ormiston, 2010: 188; Helfert, 2001: 127). Manajemen aset diproksikan sebagai Total Aset Turnover ratio (TATO), yang ditentukan dengan cara membandingkan antara total penjualan dengan total aset (Fraser \& Ormiston, 2010:193; Ehrhardt \& Brigham, 2011:94). Pada umumnya, rasio Total Asset Turnover digunakan untuk menunjukkan tingkat efektivitas penggunaan aset dalam menghasilkan penjualan (Helfert, 2001:107). Manajemen utang diproksikan sebagai Debt Ratio (DR), yang ditentukan melalui pembandingan antara total liabilitas terhadap total aset (Helfert, 2001:128; Fraser \& Ormiston, 2010:194; Ehrhardt \& Brigham, 2011:95). Pemilihan DR dipertimbangkan karena rasio ini telah digunakan secara luas 
Tabel.2. Komponen Laporan Keuangan Perusahaan (dalam miliar rupiah)

\begin{tabular}{|c|c|c|c|c|c|c|}
\hline Keterangan & Tahun & TAL & TA & $\mathrm{TL}$ & $\mathrm{TP}$ & LK \\
\hline \multirow[t]{7}{*}{ PT Asahimas Flat Glass } & 2015 & $2.231,18$ & $4.270,28$ & 880,05 & $3.665,99$ & 323,50 \\
\hline & 2014 & $2.263,73$ & $3.918,39$ & 733,75 & $3.672,19$ & 458,64 \\
\hline & 2013 & $1.980,12$ & $3.539,39$ & 778,67 & $3.216,48$ & 338,36 \\
\hline & 2012 & $1.658,47$ & $3.115,42$ & 658,33 & $2.857,31$ & 346,61 \\
\hline & 2011 & $1.473,43$ & $2.690,60$ & 545,40 & $2.596,27$ & 337,00 \\
\hline & 2010 & $1.283,71$ & $2.372,66$ & 529,73 & $2.426,14$ & 330,97 \\
\hline & 2009 & 786,50 & $1.972,40$ & 443,09 & $1.912,97$ & 67,29 \\
\hline \multirow[t]{7}{*}{ PT Surya Toto Indonesia } & 2015 & $1.348,06$ & $2.439,54$ & 948,00 & $2.278,67$ & 337,99 \\
\hline & 2014 & $1.115,00$ & $2.027,29$ & 796,10 & $2.053,63$ & 294,61 \\
\hline & 2013 & $1.089,80$ & $1.746,18$ & 710,53 & $1.711,31$ & 236,56 \\
\hline & 2012 & 966,81 & $1.522,66$ & 624,50 & $1.576,76$ & 236,70 \\
\hline & 2011 & 837,11 & $1.339,57$ & 579,03 & $1.341,93$ & 218,72 \\
\hline & 2010 & 716,49 & $1.091,58$ & 460,60 & $1.121,50$ & 194,40 \\
\hline & 2009 & 611,49 & $1.010,89$ & 482,22 & 980,33 & 182,82 \\
\hline \multirow[t]{7}{*}{ PT Arwana Citramulia } & 2015 & 509,18 & $1.430,78$ & 536,05 & $1.291,93$ & 74,23 \\
\hline & 2014 & 507,46 & $1.259,18$ & 346,94 & $1.609,76$ & 261,65 \\
\hline & 2013 & 405,11 & $1.135,24$ & 366,75 & $1.417,64$ & 237,70 \\
\hline & 2012 & 323,84 & 937,36 & 332,55 & $1.113,66$ & 158,68 \\
\hline & 2011 & 261,07 & 831,51 & 348,33 & 922,68 & 95,95 \\
\hline & 2010 & 298,44 & 873,15 & 458,09 & 830,18 & 80,11 \\
\hline & 2009 & 205,03 & 822,69 & 474,36 & 714,06 & 65,04 \\
\hline
\end{tabular}

Sumber: www.idx.co.id

dalam pengukuran manajemen utang (Helfert, 2001:128).

Mengacu pada pendapat para ahli ekonomi yang dinyatakan sebelumnya, variabel independen yang berpengaruh terhadap laba terdiri dari manajemen likuiditas, manajemen aset dan manajemen utang. Berdasarkan hal tersebut, maka hipotesis dalam penelitian ini diformulasikan sebagai berikut:

$\mathrm{H} 1$ : manajemen likuiditas secara parsial berpengaruh signifikan terhadap ROA.

$\mathrm{H} 2$ : manajemen aset secara parsial berpengaruh signifikan terhadap ROA.

H3: manajemen utang secara parsial berpengaruh signifikan terhadap ROA.
$\mathrm{H} 4$ : manajemen likuiditas, manajemen aset, dan manajemen utang secara simultan berpengaruh signifikan terhadap ROA.

\section{HASIL DAN PEMBAHASAN}

Komponen laporan keuangan perusahaan mengenai total aset lancar (TAL), total aset (TA), total liabilitas (TL), total penjualan (TP), dan laba komprehensif (LK) yang dijadikan dasar untuk menentukan rasio keuangan disajikan pada tabel 2 .

Hasil perhitungan rasio keuangan berdasarkan komponen laporan keuangan tersebut, disajikan pada tabel 3. 
Tabel. 3. Rasio Keuangan Perusahaan

\begin{tabular}{|c|c|c|c|c|c|}
\hline Keterangan & Tahun & $\mathrm{CR}$ & TATO & DR & ROA \\
\hline \multirow[t]{7}{*}{ PT Asahimas Flat Glass } & 2015 & $52,25 \%$ & $85,85 \%$ & $20,61 \%$ & $7,58 \%$ \\
\hline & 2014 & $57,77 \%$ & $93,72 \%$ & $18,73 \%$ & $11,70 \%$ \\
\hline & 2013 & $55,95 \%$ & $90,88 \%$ & $22,00 \%$ & $9,56 \%$ \\
\hline & 2012 & $53,23 \%$ & $91,72 \%$ & $21,13 \%$ & $11,13 \%$ \\
\hline & 2011 & $54,76 \%$ & $96,49 \%$ & $20,27 \%$ & $12,52 \%$ \\
\hline & 2010 & $54,10 \%$ & $102,25 \%$ & $22,33 \%$ & $13,95 \%$ \\
\hline & 2009 & $39,88 \%$ & $96,99 \%$ & $22,46 \%$ & $3,41 \%$ \\
\hline Rata-rata & & $52,56 \%$ & $93,98 \%$ & $21,08 \%$ & $9,98 \%$ \\
\hline \multirow[t]{7}{*}{ PT Surya Toto Indonesia } & 2015 & $55,26 \%$ & $93,41 \%$ & $38,86 \%$ & $13,85 \%$ \\
\hline & 2014 & $55,00 \%$ & $101,30 \%$ & $39,27 \%$ & $14,53 \%$ \\
\hline & 2013 & $62,41 \%$ & $98,00 \%$ & $40,69 \%$ & $13,55 \%$ \\
\hline & 2012 & $63,49 \%$ & $103,55 \%$ & $41,01 \%$ & $15,54 \%$ \\
\hline & 2011 & $62,49 \%$ & $100,18 \%$ & $43,22 \%$ & $16,33 \%$ \\
\hline & 2010 & $65,64 \%$ & $102,74 \%$ & $42,20 \%$ & $17,81 \%$ \\
\hline & 2009 & $60,68 \%$ & $96,98 \%$ & $47,70 \%$ & $18,09 \%$ \\
\hline Rata-rata & & $60,49 \%$ & $99,45 \%$ & $41,85 \%$ & $15,67 \%$ \\
\hline \multirow[t]{7}{*}{ PT Arwana Citramulia } & 2015 & $35,59 \%$ & $90,30 \%$ & $37,47 \%$ & $5,19 \%$ \\
\hline & 2014 & $40,30 \%$ & $127,84 \%$ & $27,55 \%$ & $20,78 \%$ \\
\hline & 2013 & $35,68 \%$ & $124,88 \%$ & $32,31 \%$ & $20,94 \%$ \\
\hline & 2012 & $34,55 \%$ & $118,81 \%$ & $35,48 \%$ & $16,93 \%$ \\
\hline & 2011 & $31,40 \%$ & $110,97 \%$ & $41,89 \%$ & $11,54 \%$ \\
\hline & 2010 & $34,18 \%$ & $95,08 \%$ & $52,46 \%$ & $9,18 \%$ \\
\hline & 2009 & $24,92 \%$ & $86,80 \%$ & $57,66 \%$ & $7,91 \%$ \\
\hline Rata-rata & & $33,80 \%$ & $107,81 \%$ & $40,69 \%$ & $13,21 \%$ \\
\hline Rata-rata keseluruhan & & $49,02 \%$ & $100,41 \%$ & $34,54 \%$ & $12,95 \%$ \\
\hline
\end{tabular}

Sumber: www.idx.co.id (data diolah)

Berdasarkan rasio-rasio keuangan tersebut, hasil uji regresi linier berganda dapat terlihat pada tabel 4 . Berdasarkan hasil pengujian regresi linier pengaruh variabelvariabel bebas terhadap ROA dapat ditentukan dengan persamaan berikut:

ROA $=-37,623+0,360$ TATO + 0,112DR + $0,217 C R$

Setelah melakukan uji regresi linier berganda, selanjutnya dilakukan uji asumsi klasik untuk mengetahui kelayakan model tersebut. Beberapa alat uji asumsi klasik yang diperlukan adalah uji normalitas, uji multikolinearitas, uji heteroskedastisitas, dan uji autokorelasi.

Dari hasil uji normalitas diketahui bahwa nilai signifikansi (Asymp.Sig 2 - tailed) sebesar 0,874. Karena tingkat signifikansi lebih besar dari 0,05 $(0,874>0,05)$, maka nilai residual terdistribusi secara normal. Hasil uji multikolinearitas menunjukkan bahwa nilai tolerance masing-masing variabel independen lebih besar dari 0,1 dan nilai VIF masing-masing variabel tersebut juga lebih kecil dari 10. Dengan demikian, 
Tabel. 4. Hasil Uji Regresi Linier Berganda

\begin{tabular}{lccccc}
\hline \multicolumn{1}{c}{ Variabel } & Koefisien & Standar Error & Beta & $t$ & Sig. \\
\hline (Constant) & $-37,623$ & 5,364 & & $-7,014$ &, 000 \\
TATO &, 360 &, 041 &, 871 & 8,759 &, 000 \\
DR &, 112 &, 041 &, 272 & 2,742 &, 014 \\
CR &, 217 &, 039 &, 568 & 5,560 &, 000 \\
\hline
\end{tabular}

dapat disimpulkan tidak terjadi masalah multikolinearitas pada model regresi.

Hasil uji Glejser menunjukkan bahwa nilai signifikansi masing-masing dari ketiga variabel independen lebih besar dari 0,05. Dengan demikian dapat disimpulkan tidak terjadi masalah heteroskedastisitas pada model regresi.

Hasil uji Durbin-Watson (DW) menunjukkan nilai sebesar 2,161. Dengan menggunakan tingkat signifikansi sebesar 0,05 pada $\mathrm{n}=21$ dan $\mathrm{k}=3$, pada tabel statistik Durbin Watson diperoleh nilai batas luar ( $\mathrm{dL}$ ) sebesar 1,026 dan nilai batas dalam (dU) sebesar 1,669. Karena hasil pengujian menunjukkan bahwa dU $<$ DW $<4$-dU $(1,669$ $<2,161<2,331)$, dapat dikatakan tidak terjadi autokorelasi dalam model regresi.

Penelitian ini juga menghasilkan nilai koefisien adjusted $R$ square $\left(R^{2}\right)$ sebesar 0,815. Hal ini berarti 81,5\% ROA dipengaruhi oleh variabel TATO, DR dan CR, sisanya dipengaruhi variabel lain yang tidak termasuk dalam pengujian ini. Berdasarkan hasil uji $\mathrm{F}$ diperoleh nilai $\mathrm{F}$ hitung sebesar 30,284 dan tingkat signifikansi sebesar 0,000. Hal ini membuktikan bahwa ketiga variabel bebas secara simultan berpengaruh terhadap ROA dengan demikian dapat disimpulkan bahwa ketiga variabel independen berpengaruh signifikan terhadap variabel dependen.
Untuk menentukan pengaruh masingmasing variabel independen terhadap laba, dilakukan dengan membandingkan antara $\mathrm{t}$ hitung dan $t$ tabel. Nilai $t$ hitung dapat terlihat pada tabel 4. Sementara, Nilai t tabel dengan tingkat signifikansi 0,05/2 $=0,025$ (uji 2 sisi), pada derajat kebebasan $\mathrm{df}=17$, diperoleh nilai t tabel sebesar $-2,080 / 2,080$.

Hasil pengujian pengaruh $C R$ terhadap laba menunjukkan bahwa $\mathrm{t}$ hitung $\mathrm{CR}>\mathrm{t}$ tabel CR $(5,560>2,080)$ dan tingkat signifikansi thitung $C R$ lebih rendah dari 0,05 , maka hipotesis $\mathrm{H} 1$ diterima. Artinya, manajemen likuiditas berpengaruh signifikan terhadap laba. Hasil penelitian ini sependapat dengan Ismail (2016), dan Novita (2015). Namun, berbeda pendapat dengan Sanjaya, dkk (2015), Ristanti, dkk (2015), Wibowo \& Wartini (2012), Barus \& Leliani (2013), dan Dwiarti (2014). Hasil penelitian ini menunjukkan bahwa jumlah aset lancar yang dimiliki perusahaan mampu untuk memenuhi kewajiban lancarnya. Kondisi ini dapat menjaga kelancaran operasional perusahaan sehingga berpengaruh terhadap laba secara signifikan.

Hasil pengujian pengaruh TATO terhadap laba menunjukkan bahwa $\mathrm{t}$ hitung TATO $>\mathrm{t}$ tabel TATO $(8,759>2,080)$ dan tingkat signifikansi t hitung TATO lebih rendah dari 0,05, maka hipotesis H2 diterima. Artinya, manajemen aset berpengaruh signifikan terhadap laba. Hasil penelitian ini 
sependapat dengan Barus \& Leliani (2013), Sari \& Chabachib (2013), dan Dwiarti (2014). Namun, berbeda pendapat dengan Sanjaya, dkk (2015). Hasil penelitian ini menunjukkan bahwa perusahaan mampu memanfaatkan seluruh aset secara efektif, sehingga berpengaruh terhadap laba secara signifikan.

Hasil pengujian pengaruh DR terhadap laba menunjukkan bahwa $\mathrm{t}$ hitung $\mathrm{DR}>\mathrm{t}$ tabel DR $(2,742>2,080)$ dan tingkat signifikansi t hitung DR lebih rendah dari 0,05, maka hipotesis H3 diterima. Artinya, manajemen utang berpengaruh signifikan terhadap laba. Hasil penelitian ini sependapat dengan Barus \& Leliani (2013), Rosyadah, dkk (2013), dan Ritonga, dkk (2014). Namun, berbeda pendapat dengan Noor \& Lestari (2012), Wibowo \& Wartini (2012) dan Kurniawati, dkk (2015). Hasil penelitian ini menunjukkan bahwa perusahaan telah mendanai sebagian asetnya dengan utang. Sementara, aset tersebut telah digunakan secara efektif sebagaimana dinyatakan sebelumnya. Dengan demikian, utang mampu memberikan berkontribusi terhadap laba secara signifikan.

\section{SIMPULAN}

Model regresi yang dihasilkan dari penelitian ini, dapat memberikan kesimpulan yang diharapkan dan sejalan dengan pendapat para ahli ekonomi yang menyatakan bahwa laba dipengaruhi oleh manajemen likuiditas (CR), manajemen aset (TATO) dan manajemen utang (DR). Dari hasil pengujian yang telah dilakukan secara parsial maupun simultan, CR, TATO dan DR sangat memengaruhi tingkat ROA. Dengan tingkat pengaruh CR, TATO dan DR terhadap ROA sebesar $81,5 \%$, berarti model regresi ini dapat digunakan untuk memprediksi variasi ROA. Namun demikian, model ini mungkin hanya dapat diterapkan untuk memprediksi laba pada perusahaan porselin, keramik dan gelas.

Mengingat bahwa variabel independen dalam pengujian ini memberikan pengaruh $81,5 \%$ terhadap laba, masih terdapat variabel lain sebesar $18,5 \%$ yang memengaruhi laba tersebut. Diharapkan bagi peneliti selanjutnya untuk dapat mengembangkan penelitian lanjutan agar dapat menemukan variabel lain tersebut.

\section{DAFTAR PUSTAKA}

Barus, A.C \& Leliani. (2013) Analisis FaktorFaktor Yang Mempengaruhi Profitabilitas Pada Perusahaan Manufaktur Yang Terdaftar di Bursa Efek Indonesia. Jurnal Wira Ekonomi Mikroskil, 3(2), 111-121.

Dwiarti, R. (2014) Evaluasi Faktor-Faktor Yang Mempengaruhi Profitabilitas Pada Perusahaan Manufaktur Yang Terdaftar di BEI. Jurnal Sosio-Humaniora, 5(2), 144161.

Ehrhardt, M.C \& Brigham, E.F. (2011) Financial Management: Theory and Practice $\left(13^{\text {th }}\right.$ Edition). Ohio: SouthWestern Cengage Learning.

Fraser, L.M \& Ormiston, A. (2010) Understanding Financial Statements $\left(9^{\text {th }}\right.$ Edition). New Jersey: Prentice Hall.

Ghozali, I. (2006) Aplikasi Analisis Multivariate dengan Program SPSS (Cetakan IV). Semarang: Badan Penerbit Universitas Diponegoro.

Helfert, E.A. (2001) Financial Analysis Tools and Techniques. New York: McGraw-Hill.

Ismail, R. (2016) Impact of Liquidity Management on Profitability of Pakistani Firms: A Case of KSE-100 Index. 
International Journal of Innovation and Applied Studies, 14(2), 304-314.

Kasmir. (2012) Analisis Laporan Keuangan. Jakarta: PT. Raja Grafindo Persada.

Keown, et.al. (2014) Foundations of Finance ( $8^{\text {th }}$ Edition). New Jersey: Pearson Education, Inc.

Kurniawati, dkk. (2015) Pengaruh Financial Leverage Terhadap Profitabilitas Pada Perusahaan Industri Kimia di BEl. Jurnal Administrasi Bisnis, 1(1), 1-9.

Noor, A.S \& Lestari, B. (2012) Pengaruh Efisiensi Modal Kerja, Likuiditas Dan Solvabilitas Terhadap Profitabilitas Pada Industri Barang Konsumsi Di Bursa Efek Indonesia Periode 2006-2009. Jurnal Spread, 2 (2), 133-138.

Novita, B.A \& Sofie. (2015) Pengaruh Struktur Modal dan Likuiditas Terhadap Profitabilitas. Jurnal Akuntansi Trisakti, 2(1), 13-28.

Platt, H.D and Platt, M.B. (2008) Financial Distress Comparison Across Three Global Regions. Journal of Risk and Financial Management, 1(1), 129-162.

Ristanti, dkk (2015) Pengaruh Likuiditas dan Efisiensi Modal Kerja Terhadap
Profitabilitas Perusahaan. Jurnal Administrasi Bisnis, 25(1), 1-8.

Ritonga, dkk. (2014) Pengaruh Financial Leverage Terhadap Profitabilitas Pada Perusahaan Makanan dan Minuman di BEI. Jurnal Administrasi Bisnis, 8(2), 1-10.

Rosyadah, dkk. (2013) Pengaruh Struktur Modal Terhadap Profitabilitas Pada Perusahaan Real Estate dan Property Yang Terdaftar di Bursa Efek Indonesia Periode 2009-2011. Jurnal Administrasi Bisnis, 3(2), 75-85.

Sanjaya, dkk. (2015). Pengaruh Likuiditas dan Aktivitas Terhadap Profitabilitas Pada PT PLN (Persero). Jurnal Manajemen Unud, 4(8), 2350-2359.

Sari, P \& Chabachib, M. (2013) Analisis Pengaruh Leverage, Efektivitas Aset dan Sales Terhadap Profitabilitas Serta Dampaknya Terhadap Nilai Perusahaan. Diponegoro Journal of Management, 2(3), 1-13.

Wibowo, A \& Wartini, S. (2012) Efisiensi Modal Kerja, Likuiditas dan Leverage Terhadap Profitabilitas Pada Perusahaan Manufaktur di BEI. Jurnal Dinamika Manajemen, 3(1), 49-58. 